\title{
Viscoelastic polyurethane foams with the addition of mint ${ }^{*)}$
}

\author{
Monika Auguścik-Królikowska1),**), Joanna Ryszkowska' ${ }^{1)}$, Leonard Szczepkowski²), \\ Dominik Kwiatkowski ${ }^{3)}$, Dorota Kołbuk-Konieczny' ${ }^{3)}$, Joanna Szymańska ${ }^{1)}$
}

DOI: dx.doi.org/10.14314/polimery.2020.3.4

\begin{abstract}
The article presents an assessment of the possibilities of producing viscoelastic open cell polyurethane (PUR) foams produced with a natural filler in the form of mint leaves. PUR foams containing from 10 to $30 \mathrm{wt} \%$ of mint were produced. Chemical structure, thermal and mechanical properties of the foams were assessed. It was found that the filler containing $7 \mathrm{wt} \%$ of water caused significant changes in the foam characteristics. In composite foams, the content of urea and hydrogen bonds increased with higher mint contents. The hardness and comfort factor of composite foams also increased. The introduction of a filler containing a significant amount of water caused a change in the porosity and wall thickness of composite foams resulting in a significant increase in their permanent deformations.
\end{abstract}

Keywords: open cell viscoelastic polyurethane foams, mint, cytocompatibility.

\section{Lepkosprężyste pianki poliuretanowe $\mathrm{z}$ dodatkiem mięty}

Streszczenie: Oceniono możliwości otrzymywania lepkosprężystych otwartokomórkowych pianek poliuretanowych z zastosowaniem napełniacza naturalnego w postaci liści mięty. Wytworzono pianki kompozytowe zawierające 10-30\% mas. liści mięty. Scharakteryzowano budowę chemiczną, strukturę, właściwości termiczne i wytrzymałościowe uzyskanych pianek. Stwierdzono, że zastosowany napełniacz, zawierający $7 \%$ mas. wody, powoduje istotne zmiany w charakterystyce pianek. Wraz ze wzrostem zawartości mięty zwiększał się udział wiązań mocznikowych i wodorowych $\mathrm{w}$ budowie otrzymanych pianek kompozytowych, zwiększyła się też ich twardość i współczynnik komfortu. Wprowadzenie napełniacza zawierającego znaczną ilość wody spowodowało również zmianę porowatości i grubości ścianek porów w kompozytowych piankach, co z kolei skutkowało znacznym zwiększeniem odkształceń trwałych.

Słowa kluczowe: otwartokomórkowe lepkosprężyste pianki poliuretanowe, mięta, biozgodność.

According to statistics [1], the average annual growth rate in the production of natural fiber composites (NFC) will increase by approx. $11 \%$ in the years $2019-2024$. Fibers and plant fillers are a renewable resource, their production requires a small amount of energy and plants are additionally associated with the absorption of $\mathrm{CO}_{2}$ and the return of oxygen to the environment [2]. The group of these composites includes both wood fiber composites and non-wood composites, composites with thermoplastic polymer matrices as well as thermosets.

\footnotetext{
1) Warsaw University of Technology, Faculty of Materials Science and Engineering, Woloska 141, 02-507 Warsaw, Poland.

2) FAMPUR Company Adam Przekurat, Gersona 40, 85-305 Bydgoszcz, Poland.

3) Institute of Fundamental Technological Research Polish Academy of Science, Pawińskiego 5B, 02-106 Warsaw, Poland.

*) The part of article was presented at the Pomerania-Plast 2019 Conference, June 5-7, 2019, Międzyzdroje, Poland.

**) Author for correspondence:

monika.auguscik.dokt@pw.edu.pl
}

NFC composites are used in various industries: automotive, construction, electrical and electronics, sport and others. Most NFC composites are used in construction, but new directions of applications for these materials are sought.

Various plant parts have been as natural fillers for the production of NFC: leaves, phloem, seeds, stems, grasses and reeds, hulls and shells, wood. A large proportion of these fillers are available in Poland: tree or tobacco leaves, flax and hemp, coffee, fruit cones and stones, corn stalks and cereals, rapeseed, nut shells, cereal hulls, corn and sunflower and various types of wood [3-9]. Herbs can be used as fillers to improve the utility of the products [10]. Herbs have been used in natural medicine for many years. In their structure, there are components with low molar mass, i.e. alkaloids, flavonoids, saponins and components with high molar mass: proteins, tannins and polysaccharides [11, 12]. As a result of research, it was found that polysaccharides are one of the main components determining the different pharmacological effects of herbs, i.e. immunostimulatory activity, antiviral, antioxidant, antitumor activity or antifatigue effect [13-17]. One of 
the most popular herbs is mint, which contains essential oils, tannins, as well as beneficial health flavonoids that include: luteolin, rutin, hesperidin, as well as phenolic acids [18]. Alternative therapies use peppermint leaves and oil. It is used in many alternative therapies such as irritable bowel syndrome, flatulence, indigestion, nausea, vomiting, coughing and bronchitis [19-21]. Essential oil and peppermint extracts show antimicrobial, antiviral, fungicidal, insecticidal and antioxidant activity [22-24]. Peppermint has a beneficial effect on the nervous system, reduces headaches associated with nervous tension [18].

The research presented in the article concerns polyurethane composites with a filler in the form of ground mint leaves, which can be used as pillows, mattresses and foundations. The benefits of essential oil and extracts contained in mint leaves can be used in these applications.

Many scientific papers have been devoted to polyurethane composites with natural fillers, they concerned both elastomers and various groups of polyurethane foams [25-30]. However, so far no herbs have been used to make biocomposite foams with open cell viscoelastic polyurethane foam (VEPUR).

\section{EXPERIMENTAL PART}

\section{Materials}

The matrix of the composite was viscoelastic open cell foam (VEPUR), described in the patent PL407875-A1. Foams were produced with the isocyanate index $I N C O=80$. The following components were used to make the materials:

- polyol Arcol 1374 Covestro,

- polyol Daltocel F526 Huntsman Polyurethanes,

- polyol Rokopol M1170, G1000 PCC Rokita SA, Poland,

- isocyanate Ongronat 4040 BorsodChem, Hungary,

- foaming agent, water,

- catalyst Jeffcat DPA (Huntsman),

- catalyst Jeffcat ZF-10,

- surfactant Tegostab B 4900.

Kawon peppermint leaves ground in an impact mill were used as a filler.

\section{Synthesis of foams}

The foams were produced by a one-step method. Polyol component A containing polyols, catalysts, surfactants, water, catalysts, and filler were prepared for the composite foams.

Then, using a stirrer at $3000 \mathrm{rpm}$, component A was mixed for $10 \mathrm{~s}$, then component A was mixed with component B (isocyanate) for $10 \mathrm{~s}$ and poured into an open rectangular mold.

During the synthesis, the start time and foam growth time were recorded. After the synthesis, the foam was heated at $70{ }^{\circ} \mathrm{C}$ for an hour, then seasoned for 7 days at room temperature. Only after this time, test samples were cut.

\section{Methods of testing}

- The apparent density $(D)$ was calculated by measuring the mass and volume of the sample. The mass of the samples was determined with an accuracy of $\pm 0.001 \mathrm{~g}$, and the dimensions of the samples were measured with an accuracy of $\pm 0.01 \mathrm{~mm}$.

- The chemical composition was analyzed using a Nicolet 6700 (Thermo Electron Corporation) FT-IR spectrophotometer equipped with an ATR unit (suppressed total reflection). Each sample was scanned 64 times in the $4000-400 \mathrm{~cm}^{-1}$ wavelength range, absorption spectra were recorded. The results were analyzed using OMNIC Spectra 2.0 software (Thermo Nicolet).

- Thermogravimetric analysis was performed using TGA Q500 TA Instruments under a nitrogen atmosphere. Samples of approximately $10 \mathrm{mg}$ were heated in platinum dishes from room temperature to $800{ }^{\circ} \mathrm{C}$, with a heating rate of $10^{\circ} \mathrm{C} / \mathrm{min}$.

- Differential scanning calorimetry was performed using a DSC Q1000 from TA Instruments. Measurements were made in helium atmosphere in hermetic aluminum crucibles. Samples of approximately $6 \mathrm{mg}$ were heated from -90 to $180{ }^{\circ} \mathrm{C}$ with a heating rate of $10^{\circ} \mathrm{C} / \mathrm{min}$.

- A Hitachi SEM TM3000 scanning electron microscope was used to observe the microstructure of the produced materials. Before observation, filler and foam samples were sprayed with a palladium gold layer. Observations were made using a $5 \mathrm{keV}$ voltage.

- Compressive permanent deformation was determined on $50 \times 50 \times 50 \mathrm{~mm}$ samples in the direction of foam growth. Foams were compressed by $50 \%, 75 \%$ and $90 \%$ of the original height in metal covers. Then they were placed in an oven at $70{ }^{\circ} \mathrm{C}$ for 22 hours. After this time, the samples were removed from the metal covers and after 0.5 hour at room temperature their height was again measured. The percentage loss in height of samples was calculated, thus determining permanent deformation.

- The foam compression process on the testing machine was also assessed. The samples were compressed by $75 \%$ of their height. The value of compressive stresses during loading and unloading was obtained, thus obtaining a hysteresis loop. Each sample was squeezed 4 times. The comfort coefficient of the foam (stress at 65\% compression of the sample/stress at $25 \%$ height of the sample) and the hardness of the foam (stress at $40 \%$ height of the sample) were determined on the basis of the compression test.

- Particle size was determined in a Horiba LA-950 laser particle size analyzer using the LALLS (low angle laser light scattering) technique to achieve full geometric and morphological characteristics of powders. The measurements were carried out with the refractive index specific to cellulose (1.47) laser setting, which reports the full geometrical and morphological characteristics of powders.

- The water content in the filler was assessed using a moisture analyzer type Radwag MA200/1.X2.A at $60^{\circ} \mathrm{C}$. 
- Cell cultures: Biological studies were performed using L929 mouse fibroblasts (Sigma-Aldrich). Cells were cultured in $75 \mathrm{~cm}^{2}$ flasks in culture medium and held in an incubator. Cells were removed from the flask using $0.05 \%$ trypsin. The harvested cells with the addition of $5 \mathrm{~cm}^{3}$ of culture medium were then centrifuged for 5 minutes at $100 \mathrm{~g}$. The collected pellet was resuspended with culture medium and diluted to the required cell density. The number of cells was measured using a TC2 Automated Cell Counter Bio-Rad.

Sample preparation: all materials were cut into disks of $8 \mathrm{~mm}$ diameter and a thickness of $3 \mathrm{~mm}$, suitable for 48 well plates. Cut samples were sterilized in UV light for 30 minutes on each side.

- The cytotoxicity of samples was determined on extracts in the Presto Blue test: in order to obtain extracts for the cytotoxicity test, 3 samples of each cylindrical part (disks of $8 \mathrm{~mm}$ diameter and thickness of $3 \mathrm{~mm}$ ) were placed in a 48-well plate. They were immersed in $0.6 \mathrm{~cm}^{3}$ of culture medium per well, and kept at $37^{\circ} \mathrm{C}$. For reference, along with wells with samples, 3 wells without material were filled with medium as well.

At the same time L929 cells were seeded into another 48-well plate with a density of $15 \times 103$ cells/well and put in an incubator for 24 hours. After that time, the culture medium from cell seeded wells was replaced with sample extracts and the plate was placed in the incubator for another 24 hours. Additionally, culture media in 3 wells with cells was replaced with pure culture media and they were used as a control (TCP - tissue culture plastic). Finally, the Presto Blue test was performed according to the Thermo Fisher Scientific protocol. Samples were washed with PBS (phosphate buffered saline) to remove residual culture medium. Afterwards, each well was filled with $0.09 \mathrm{~cm}^{3}$ of PBS and $0.01 \mathrm{~cm}^{3}$ of Presto Blue reagent and then the plate was returned to the incubator for $60 \mathrm{~min}$. When this step was completed, $0.1 \mathrm{~cm}^{3}$ from each well was transferred to a 96-well plate. Fluorescence was read with excitation/emission 530/620 nm filters using apparatus FLUOstar Omega.

- To assess the effect of mint addition in the tested concentrations of 10, 20,30 wt \%, an evaluation of bacterial growth on agar plates was carried out. In this study we used Escherichia coli DH5 $\alpha$ strain. The culture was carried out on agar lysogen broth (LB) medium. $5 \times 5 \mathrm{~mm}$ of material fragments with the addition of mint were soaked with $0.05 \mathrm{~cm}^{3}$ of bacterial inoculum (100 colony forming unit per milliliter) and left for 24 hours in an incubator to fix bacterial cells in the material. Next, the soaked fragments were placed in Petri dishes (three for each sample) with $50 \mathrm{~cm}^{3} \mathrm{LB}$ agar medium. Incubation was performed in a microbiological incubator Binder BD56 (Binder $\mathrm{GmbH}$, Tuttlingen, Germany) at $37^{\circ} \mathrm{C}$ for 96 hours. The colony growth around the soaked material was assessed with a stereo microscope ZEISS Stemi 508 (ZEISS, Oberkochen, Germany). Digimizer software (MedCalc Software dv, Ostend, Belgium) was used to quantitati- vely measure the agar surface coverage of the bacterial colony. The effect of mint addition was assessed by the t-student with $\alpha=0.05$ statistical significance.

\section{RESULTS AND DISCUSSION}

The properties of composite foams with natural fillers are influenced by many features of fillers, i.e. type of fibers, method of their preparation, shape factor, chemical structure and structure of the filler, its content and dispersion in the matrix [2]. Therefore, the research began with the characterizing the filler.

\section{Filler}

Vegetable fillers, including mint are made of ingredients called $1^{\text {st }}$ and $2^{\text {nd }}$ order. The first group includes hemicellulose, cellulose and lignin, and the second depends on the type of filler: proteins, waxes, fats, pectin, tannins, resins, dyes and mineral salts [31-34]. The share of individual primary ingredients and the type and amount of secondary ingredients determine the properties of the filler [3-6]. To assess the chemical structure of the filler, ATR-FTIR analysis was performed (Fig. 1).

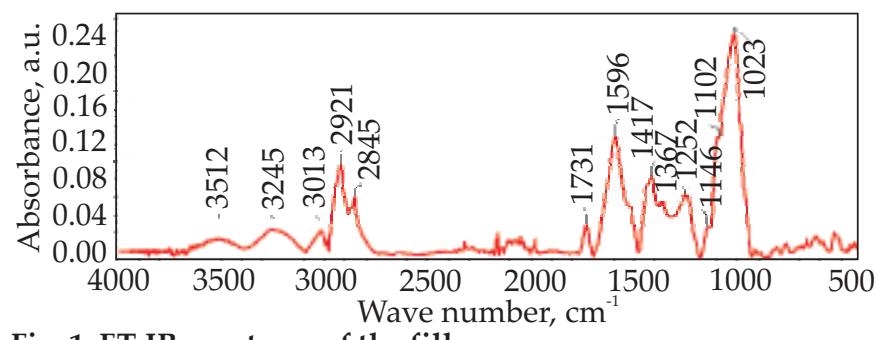

Fig. 1. FT-IR spectrum of the filler

The bands in the spectrum indicate that the tested filler contains alcohols, phenols, aldehydes, flavonoids, amines and amides, and others, forming primary and secondary structures in mint.

The spectrum shows a very wide and intense band in the range of $3670-3380 \mathrm{~cm}^{-1}$ resulting from the vibrations of the $\mathrm{OH}$ groups of alcohols and polyphenols, which in mint can be even 19\% [35] and un associated $\mathrm{OH}$ groups [36]. Bandwidth in the range $3380-3100 \mathrm{~cm}^{-1}$ resulting from vibrations of associated $\mathrm{H}_{2} \mathrm{O}$ molecules and $\mathrm{OH}$ groups bound by hydrogen bonds $[37,38]$. Both bands can be derived from inter- and intra-molecular bonds connecting hydroxyl groups in cellulose particles [37]. At wave numbers $2924 \mathrm{~cm}^{-1}$ and $2848 \mathrm{~cm}^{-1}$ there are bands originating from the asymmetrical stretching vibrations of $\mathrm{CH}$ bonds in mint particles [37]. There is also a band of considerable intensity at $1737 \mathrm{~cm}^{-1}$, associated with vibrations of carbonyl groups $(\mathrm{C}=\mathrm{O})$ [39] or aliphatic esters [40]. A sharp peak at $1596 \mathrm{~cm}^{-1}$ is associated with vibrations of aromatic groups in compounds containing carbonyl groups [41]. The band at $1376 \mathrm{~cm}^{-1}$ is the result of C-N band vibrations from aromatic groups in amines [42]. The $1420 \mathrm{~cm}^{-1}$ (COO-) and $1255 \mathrm{~cm}^{-1}$ (C-O) bands are probably 
a)

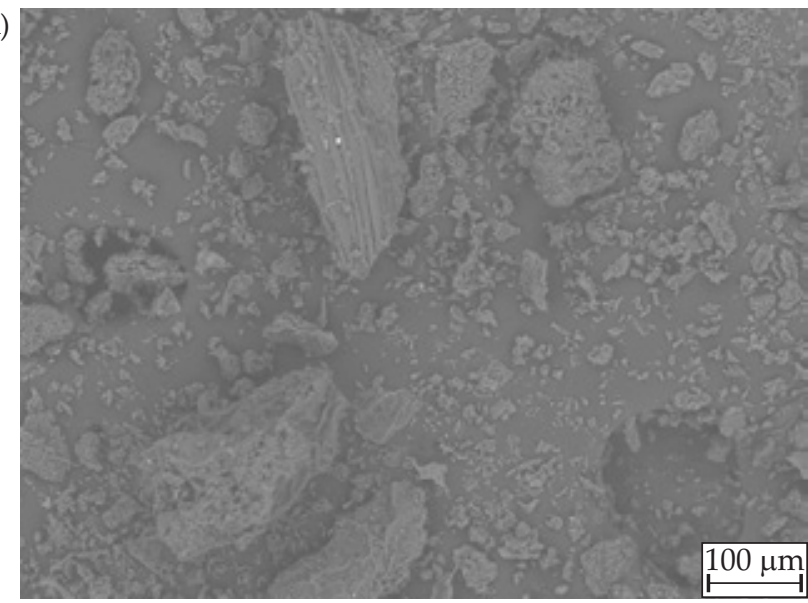

b)

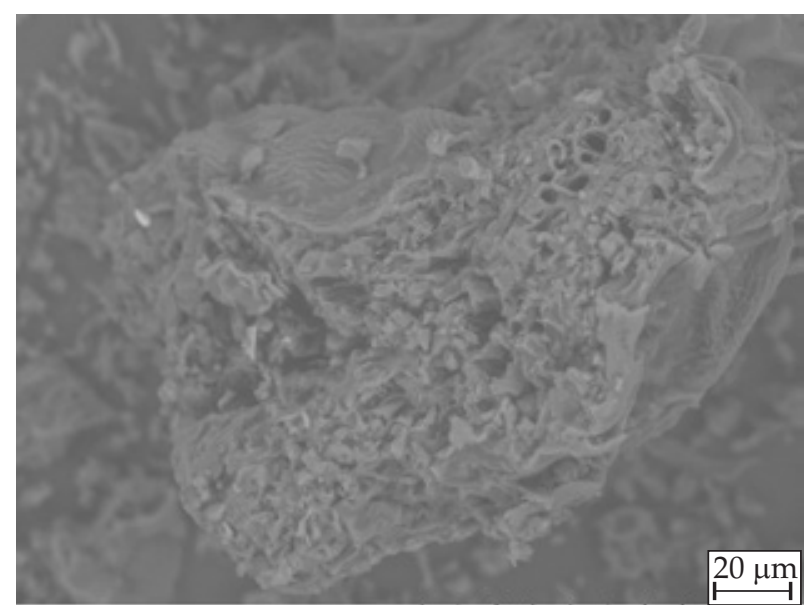

Fig. 2. Images of the filler particles microstructure at magnification: a) $200 \times$, b) $800 \times$

associated with the vibrations of various carbohydrates forming primary structures in mint particles [40]. The $1014 \mathrm{~cm}^{-1}$ band is derived from nucleic acids [43].

The chemical structure of the fillers, as well as their shape and size, affect the properties of the thermoplastic and thermoset composites with natural fillers [44-46]. Therefore, microscopic observations of mint prepared for use as a filler were made. The results of the observation of the microstructure of ground mint leaves are presented in Fig. 2.

Based on the SEM images (Fig. 2a), it can be concluded that the filler particles have varied irregular shapes similar to cylinders or flakes and a size smaller than $1 \mathrm{~mm}$. The interior of the particles have a microporous structure (Fig. 2b).

The particle size of the filler in isopropanol was analyzed using a laser analyzer, and the results of particle size analysis are presented in Fig. 3.

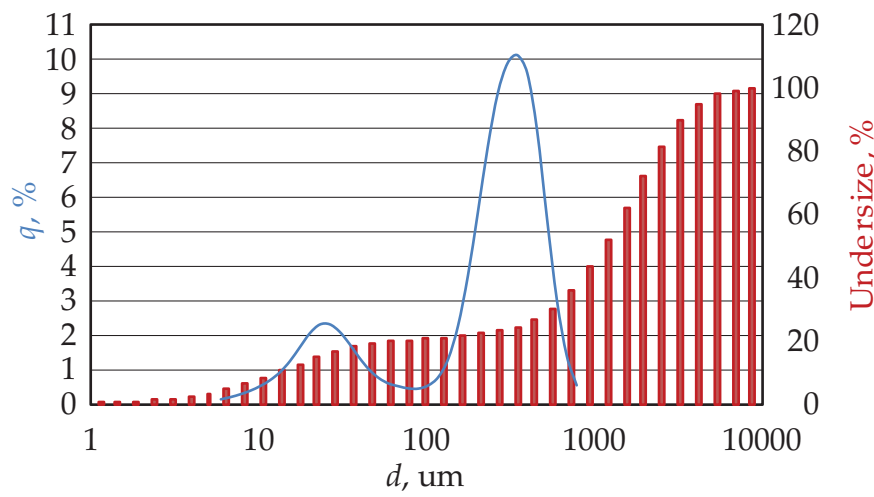

Fig. 3. Mint filler particles size distribution

The median particle size is $254 \mu \mathrm{m}$ and the mode value calculated from the measurement was $321 \mu \mathrm{m}$. Two maxima were observed on the curve with particle sizes of about $26 \mu \mathrm{m}$ and $344 \mu \mathrm{m}$.

The water content in the filler was assessed using a moisture analyzer, and the determination found that the filler contained $6.8 \mathrm{wt} \%$ water. Based on the results of the analysis of various groups of plant fillers, it was found that the several stages can be distinguished during their thermal degradation. The first of them is the stage ending at a temperature of about $200{ }^{\circ} \mathrm{C}$, associated with the release of water, including bound water and secondary ingredients, i.e. waxes, proteins, fats, resins, tannins, dyes and pectins. The next stages of degradation are associated with the degradation of the so-called primary components: hemicellulose, cellulose and lignin in the temperature range: $200-270{ }^{\circ} \mathrm{C}, 250-350{ }^{\circ} \mathrm{C}$ and $280-$ $500{ }^{\circ} \mathrm{C}$, respectively. After the degradation of these components, aromatic substances remain, which may occur at a temperature of about $675^{\circ} \mathrm{C}$ [47-50].

The results of the TGA analysis of the filler in the form of ground mint leaves are shown in Fig. 4.

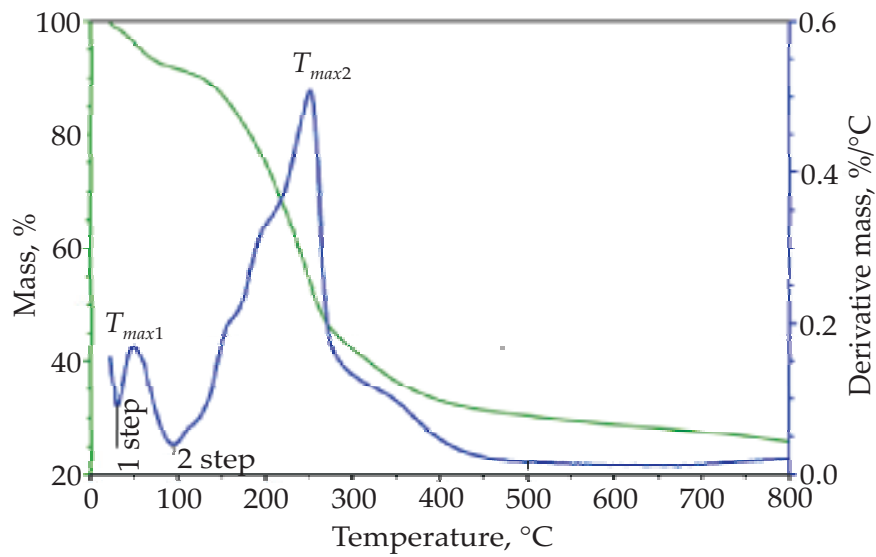

Fig. 4. Results of the TGA analysis of the filler in the form of mint leaves

Two distinct steps related to mint degradation were observed on the sample mass change curves (TG), which are clearly visible on the mass derivative curve (DTG).

The first with the maximum degradation rate $T_{\max 1}$ and the second with $T_{\max 2}$. The description of these stages is presented in Table 1.

During the first stage of degradation, $7.2 \%$ of the sample mass dropped, while the value determined on the basis of analysis using a moisture analyzer at $60{ }^{\circ} \mathrm{C}$ was $0.4 \%$ lower. 
T a b l e 1. Results of the filler DTG curve analysis

\begin{tabular}{|c|c|c|c|}
\hline $\begin{array}{c}T_{\max } \\
{ }^{\circ} \mathrm{C}\end{array}$ & $\begin{array}{c}\text { Peak } \\
\text { temperature } \\
\text { stage } \\
{ }^{\circ} \mathrm{C}\end{array}$ & $\begin{array}{c}\text { Mass loss in } \\
\text { the stage } \\
\%\end{array}$ & $\begin{array}{l}\text { Description of the } \\
\text { stage }\end{array}$ \\
\hline 50 & 30-100 & 7.2 & $\begin{array}{l}\text { Water and other } \\
\text { easily volatile } \\
\text { compounds }\end{array}$ \\
\hline 250 & $100-500$ & 62.8 & $\begin{array}{l}\text { Other filler } \\
\text { ingredients }\end{array}$ \\
\hline
\end{tabular}

Several bends are also visible on the DTG curve, however, their interpretation is difficult, and so it was decided to analyze the multiplet peak describing the second degradation stage to degradation. The distribution was carried out using the Gauss method with a resolution of $2{ }^{\circ} \mathrm{C}$, the results of the distribution are shown in Fig. 5 .

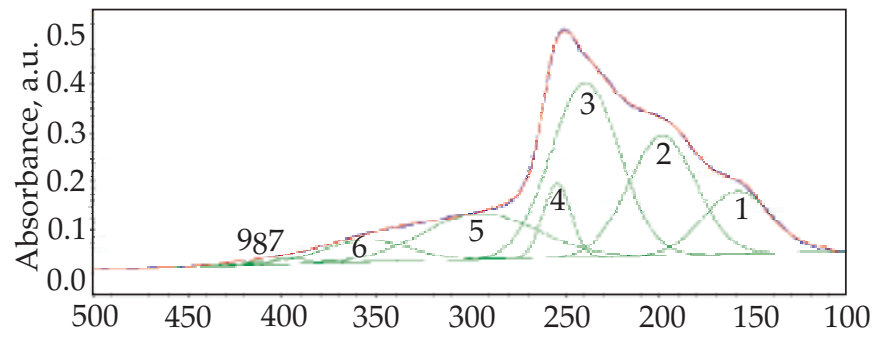

Fig. 5. Results of the DTG multiplet peak distribution describing the second degradation stage

Within this multiplet peak, 9 component peaks are distinguished, whose description is presented in Table 2:

$\mathrm{T}$ a b 1 e 2. Description of the component peaks of the DTG multiplet band in the range of $100-500{ }^{\circ} \mathrm{C}$ describing the degradation of mint leaves

\begin{tabular}{|c|c|c|c|}
\hline $\begin{array}{c}T_{\max } \\
{ }^{\circ} \mathrm{C}\end{array}$ & $\begin{array}{c}\text { Peak } \\
\text { temperature } \\
\text { stage } \\
{ }^{\circ} \mathrm{C} \\
\end{array}$ & $\begin{array}{c}\text { Mass loss in } \\
\text { the stage } \\
\%\end{array}$ & $\begin{array}{l}\text { Description of the } \\
\text { stage }\end{array}$ \\
\hline 159 & $100-220$ & 7.7 & $\begin{array}{l}\text { Bound water, } \\
\text { phenols, amides }\end{array}$ \\
\hline 199 & $140-270$ & 14.9 & Hemicellulose \\
\hline 240 & $170-310$ & 22.1 & Cellulose \\
\hline 255 & $200-300$ & 3.8 & Cellulose \\
\hline 296 & 190-390 & 9.8 & Lignin \\
\hline 356 & $280-420$ & 3.7 & Lignin \\
\hline 399 & $360-500$ & 0.6 & $\begin{array}{l}\text { Decomposition } \\
\text { of degradation } \\
\text { products from } \\
\text { previous stages }\end{array}$ \\
\hline 425 & $360-500$ & 0.2 & $\begin{array}{l}\text { Decomposition } \\
\text { of degradation } \\
\text { products from } \\
\text { previous stages }\end{array}$ \\
\hline 446 & $360-500$ & 0.0 & $\begin{array}{l}\text { Decomposition } \\
\text { of degradation } \\
\text { products from } \\
\text { previous stages }\end{array}$ \\
\hline
\end{tabular}

$30.0 \%$ of the filler mass remained after the degradation stages described in the Table 2, aromatic compounds and ashes could remain in this mass.

\section{Foams - composite foams}

VEPUR biocomposites containing filler in the form of ground mint leaves were prepared, the description of which is given in Table 3.

T a b l e 3. Parameters of syntheses and description of samples

\begin{tabular}{c|c|c|c|c}
\hline Sample & $\begin{array}{c}\text { Content } \\
\text { of mint } \\
\text { filler, wt \% } \\
\text { (on the } \\
\text { amount } \\
\text { of polyol } \\
\text { mixture) }\end{array}$ & $\begin{array}{c}\text { Start time } \\
\text { s }\end{array}$ & $\begin{array}{c}\text { Growth } \\
\text { time } \\
\text { s }\end{array}$ & INCO \\
\hline VEPUR & 0 & 18 & 148 & 80 \\
VEPUR 10 & 10 & 20 & 152 & $74^{*}$ \\
VEPUR 20 & 20 & 20 & 137 & $69^{*}$ \\
VEPUR 30 & 30 & 19 & 136 & $65^{*}$ \\
\hline
\end{tabular}

* Isocyanate index (INCO) after taking into account the water contained in the filler and assuming that this water has reacted with NCO groups.

During the synthesis, the start and growth times of the foams were recorded. The start time is about 19 seconds and ranges over 2 seconds. On the other hand, the growth time lengthened after the introduction of $10 \mathrm{wt} \%$ of filler, and shortened with a further increase in its amount. Table 3 also contains the value of the isocyanate index calculated after taking into account the water introduced into the reaction mixture together with the filler, assuming that the fillers contained $7 \mathrm{wt} \%$ of water.

FT-IR analysis enabled the detection and identification of bonds and moieties found in the tested foams. A stack of spectra of tested foams is presented in Fig. 6 .

The foams were made at the isocyanate index of 80 , therefore no peak was observed in the spectra in the 2240 $2270 \mathrm{~cm}^{-1}$ band originating from the NCO group [51].

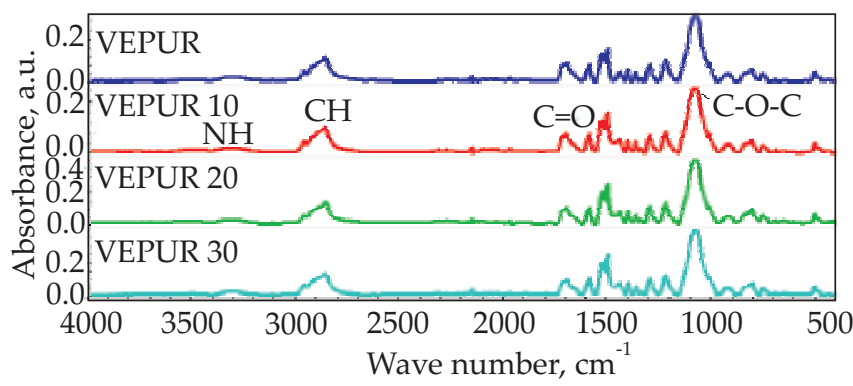

Fig. 6. Stack of FT-IR spectra of prepared foams 
The 3336-3342 $\mathrm{cm}^{-1}$ band is associated with symmetrical and asymmetrical stretching of $\mathrm{NH}$ bonds [52, 53].

In all spectra, bands corresponding to symmetrical (2868-2869 cm-1 band) and asymmetrical (2969-2970 cm-1 band) $\mathrm{CH}_{2}$ groups were identified [52]. The 1707-1708 $\mathrm{cm}^{-1}$ band is characteristic for $\mathrm{C}=\mathrm{O}$ stretching bonds. And the presence of urethane groups in foams is evidenced by the $1509 \mathrm{~cm}^{-1}$ band associated with C-N vibrations and/or stretching $\mathrm{C}=\mathrm{O}$ bonds [51]. In contrast, the $1452-1453 \mathrm{~cm}^{-1}$ and $1373 \mathrm{~cm}^{-1}$ peaks come from different types of $\mathrm{CH}_{2}$ vibrations [51]. The 1534-1536 $\mathrm{cm}^{-1}$ band comes from bending vibrations of $\mathrm{CH}$ bonds in the $\mathrm{CH}_{2}$ groups [51]. A peak in the $1306 \mathrm{~cm}^{-1}$ range indicates the occurrence of characteristic vibrations for bending vibrations of $\mathrm{CH}_{3}$ groups [54]. The $1086-1089 \mathrm{~cm}^{-1}$ band comes from the vibrations of $\delta$ bonds occurring in the $\mathrm{C}-\mathrm{O}$ group [54]. The band ranges of $763-764 \mathrm{~cm}^{-1}$ and $816 \mathrm{~cm}^{-1}$ are associated with the occurrence of $\mathrm{CH}$ bonds in aromatic rings [54]. The band from vibrations of aromatic isocyanate groups occurs at a frequency of $1597 \mathrm{~cm}^{-1}$, and this allows spectral scaling because all the foams use the same amount of isocyanate. In order to analyze changes in the structure of the hard phase of foams, the multiplet band was characterized by vibrations of carbonyl groups in the range of $1760-1630 \mathrm{~cm}^{-1}$ (Fig. 7). The course of the analysis is described in [54], and the results of this band's distribution are presented in Table 4 . The share of hydrogen bonds $(R)$, the degree of phase separation (SSF) and the share of urea and urethane bonds in the tested foams were calculated.

The introduction of a $10 \mathrm{wt} \%$ of filler promotes the formation of hydrogen bonds in the hard phase of the obtained composite foams, and also changes the share of urea and urethane bonds in the resulting foams. The introduction of a $10 \mathrm{wt} \%$ of filler results in an increase by $5 \%$ in the share of urethane bonds compared to foam without filler. The level of urethane bonds in composite foams may be affected by the reaction of $\mathrm{OH}$ groups of cellulose with NCO groups of isocyanate [55]. Ryabov et al. [56] proved that in reaction with NCO groups, the

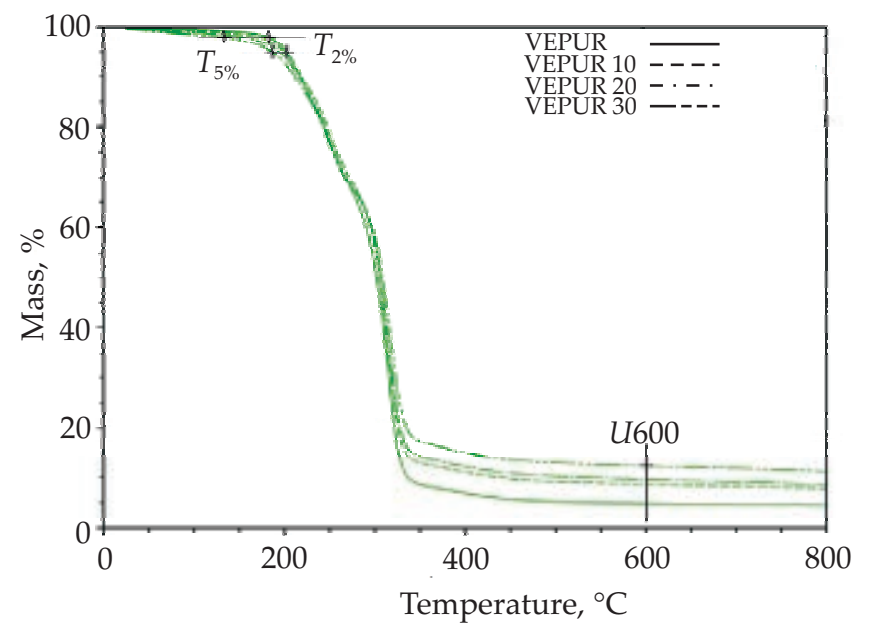

Fig. 8. Summary of curves from thermogravimetric analysis (TG)

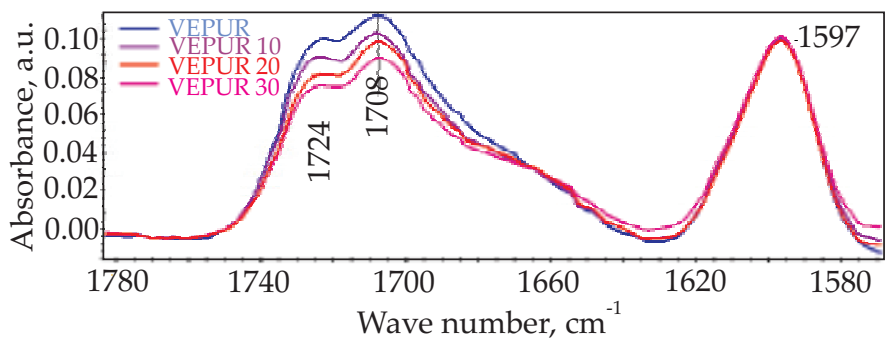

Fig. 7. Multiplet band in the range corresponding the vibrations of carbonyl groups and the band of the vibrations of aromatic groups containing in tested foams structure

$\mathrm{T}$ a b 1 e 4 . Results of the analysis of the multiplet bandwidth distribution of carbonyl groups contained in the building of prepared foams

\begin{tabular}{c|c|c|c|c}
\hline Sample & $R$ & SSF & $\begin{array}{c}\text { The share of } \\
\text { urea bonds } \\
\%\end{array}$ & $\begin{array}{c}\text { The share } \\
\text { of urethane } \\
\text { bonds, } \%\end{array}$ \\
\hline VEPUR & 1.56 & 0.61 & 51 & 49 \\
VEPUR 10 & 3.01 & 0.75 & 46 & 54 \\
VEPUR 20 & 2.79 & 0.74 & 51 & 49 \\
VEPUR 30 & 1.95 & 0.66 & 61 & 39 \\
\hline
\end{tabular}

$\mathrm{OH}$ groups from the glucose unit of starch reacted much faster than with moisture in the air. A similar situation may occur when the $\mathrm{OH}$ groups of polysaccharides in cellulose react with NCO groups. Because the isocyanate index is less than 100, the water remaining in the reaction medium does not react completely due to the lack of $\mathrm{OH}$ groups. Further increasing the share of the filler increases the share of urea bonds. This is probably the result of an increase in the proportion of water in the reaction medium released from the filler. The introduction of 20 and $30 \mathrm{wt} \%$ of filler significantly reduces the growth time of foams, which can be caused by a significant increase in the amount of water in the reaction environment.

Thermogravimetric analysis was also carried out for the foams, the results are illustrated in Figs. 8 and 9.

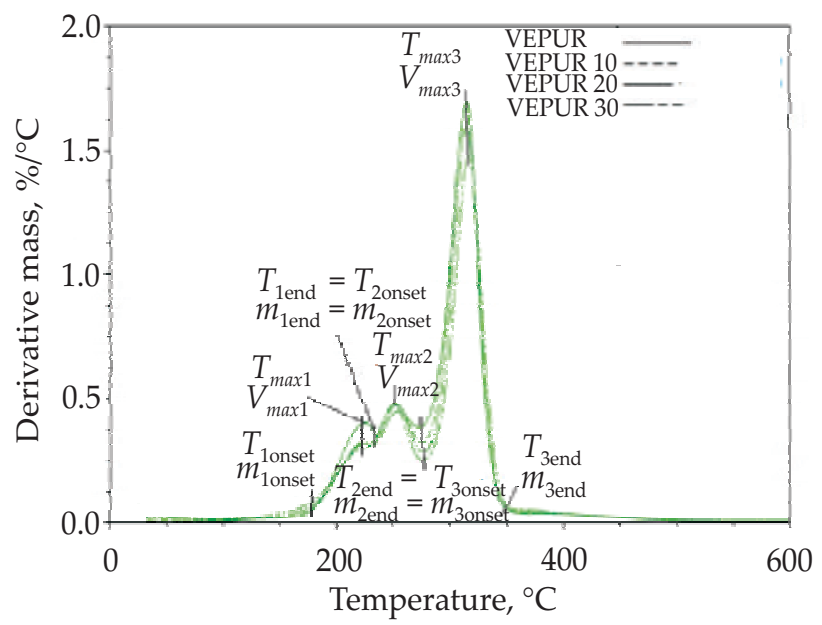

Fig. 9. Summary of curves derived from foam mass changes as a function of temperature (DTG) 
T a b l e 5. The results of the analysis of TG and DTG curves of prepared foams

\begin{tabular}{|c|c|c|c|c|c|}
\hline \multirow{2}{*}{ Parameter } & \multicolumn{4}{|c|}{ Sample } & \multirow{2}{*}{ The tendency of parameter changes } \\
\hline & VEPUR & VEPUR 10 & VEPUR 20 & VEPUR 30 & \\
\hline $\mathrm{T}_{2 \%},{ }^{\circ} \mathrm{C}$ & 182 & 171 & 154 & 133 & Reduction \\
\hline$T_{5 \%},{ }^{\circ} \mathrm{C}$ & 202 & 200 & 195 & 187 & Reduction \\
\hline$T_{\text {lonset }^{\prime}}{ }^{\circ} \mathrm{C}$ & 178 & 172 & 170 & 166 & Reduction \\
\hline$m_{\text {1onset' }} \%$ & 98.3 & 98.0 & 97.4 & 96.8 & Increase in cavity \\
\hline$T_{\max 1^{\prime}}{ }^{\circ} \mathrm{C}$ & 223 & 224 & 224 & 220 & Constant \\
\hline$V_{\max 1}, \% /{ }^{\circ} \mathrm{C}$ & 0.40 & 0.32 & 0.33 & 0.30 & Decrease compared to VEPUR \\
\hline$T_{\text {1end' }} T_{\text {2onset' }^{\prime}}{ }^{\circ} \mathrm{C}$ & 236 & 231 & 231 & 228 & Reduction \\
\hline$m_{1 \text { end }}, m_{\text {2onset }^{\prime}} \%$ & 82.9 & 86.4 & 85.3 & 85.3 & Increase compared to VEPUR \\
\hline$\Delta m_{1}, \%$ & 15.4 & 11.6 & 12.1 & 11.5 & Decrease compared to VEPUR \\
\hline$T_{\max 2^{\prime}}{ }^{\circ} \mathrm{C}$ & 253 & 253 & 252 & 250 & Slight decrease \\
\hline$V_{\max 2}, \% /{ }^{\circ} \mathrm{C}$ & 0.45 & 0.47 & 0.48 & 0.48 & Slight increase compared to VEPUR \\
\hline$T_{\text {2end' }} T_{\text {3onset' }^{\circ}}{ }^{\circ} \mathrm{C}$ & 274 & 275 & 276 & 275 & Constant \\
\hline$m_{\text {2end }} m_{\text {3onset' }} \%$ & 67.5 & 69.0 & 67.5 & 67.6 & Constant \\
\hline$\Delta m_{2}, \%$ & 15.4 & 17.4 & 17.8 & 17.7 & Increase compared to VEPUR \\
\hline$T_{\max 3^{\prime}}{ }^{\circ} \mathrm{C}$ & 314 & 313 & 314 & 315 & Constant \\
\hline$V_{\max 3^{\prime}} \% /{ }^{\circ} \mathrm{C}$ & 1.70 & 1.67 & 1.60 & 1.48 & Reduction \\
\hline$T_{\text {3end }}{ }^{\circ} \mathrm{C}$ & 352 & 353 & 351 & 352 & Constant \\
\hline$m_{3 \text { end }} \%$ & 8.5 & 12.9 & 14.3 & 17.3 & Increase \\
\hline$\Delta m_{3} \%$ & 59.0 & 56.1 & 53.2 & 50.3 & Reduction \\
\hline$U_{600}, \%$ & 4.7 & 8.7 & 9.7 & 12.4 & Increase \\
\hline
\end{tabular}

On the basis of the TG thermogram curves, the temperature of $2 \%$ mass loss $\left(T_{2 \%}\right)$, temperature of $5 \%$ mass loss $\left(T_{5 \%}\right)$ and degradation residue at $600^{\circ} \mathrm{C}$ were determined.

However, on the basis of DTG curves, the temperature of the beginning and end of individual degradation stages $T_{\text {onset }}$ and $T_{\text {end }}$, as well as the mass loss at the beginning and end of each stage ( $m_{\text {onset }}$ and $m_{\text {end }}$ ) were determined, which allowed the determination of the change in mass during $\Delta m$. The maximum degradation rate $\left(V_{\max }\right)$ and the temperature at which the maximum degradation rate $\left(T_{\max }\right)$ of each stage was reached were also determined.

The course of the analysis is schematically presented in Figs. 8 and 9, and the results of the analysis for all foams are presented in Table 5. This table also indicates the tendency in change for each of the foam features.

The introduction of a filler causes a clear decrease in the $2 \%$ mass loss temperature associated with the loss of water and easily volatile substances contained in foams, and a $T_{5 \%}$ temperature often considered as the onset temperature of polyurethane degradation. The first stage of degradation of foams takes place in the range of $172 \pm 6$ to $232 \pm 4{ }^{\circ} \mathrm{C}$, the second stage of degradation ends at $275 \pm 1{ }^{\circ} \mathrm{C}$, and the third ends at $352 \pm 1^{\circ} \mathrm{C}$. During the first stage of the decomposition process, the hard phase of foams degrade, probably most urea bonds, and in composite foams additionally the degradation of hemicellulose. Increasing the amount of hydrogen bonds in the hard phase hinders the degradation of this phase, which means that composite foams are degraded by about $25 \%$ less bonds than in VEPUR. The rate of degradation at this stage clearly decreases, indicating that bonding between $\mathrm{OH}$ cellulose groups and $\mathrm{NCO}$ groups of the matrix-forming isocyanate may have occurred. The second stage of the process is associated with the degradation of the hard phase and in cellulose filler composite foams. Mass loss at this stage may result from the distribution of urethane bonds in the hard phase $[57,58]$. At this stage, the degradation rate in composite foams increases and the mass loss increases by approx. $15 \%$.

The third degradation stage is related to the soft phase distribution of foams and in the lignin contained in the filler. In the third stage of degradation, the rate of degradation in composite foams significantly decreases compared to unmodified foam, and with increasing amount of filler used. The mass loss in this stage decreased by approx. 5, 10 and $15 \%$, respectively.

After decomposition at $600{ }^{\circ} \mathrm{C}$, as the amount of filler increased, the amount of ash remaining after degradation of the filler increased.

Figure 10 lists DSC thermograms for unmodified foam, composite foams and mint, while Table 6 summarizes the results of the analysis.

In the mint sample, the glass transition temperature and two endothermic peaks associated with crystalline phase melting were observed [57]. It is likely that these changes occur in two phases of cellulose made up of macromolecules of different length that form the mint structure. 
T a b l e. 6. Summary of DSC analysis results

\begin{tabular}{|c|c|c|c|c|c|c|}
\hline Sample & $T_{g^{\prime}}{ }^{\circ} \mathrm{C}$ & $\Delta C_{p^{\prime}} \mathrm{J} /\left(\mathrm{g} \cdot{ }^{\circ} \mathrm{C}\right)$ & $T_{t 1}{ }^{\circ} \mathrm{C}$ & $\Delta H_{t 1^{\prime}} \mathrm{J} / \mathrm{g}$ & $T_{t 2^{\prime}}{ }^{\circ} \mathrm{C}$ & $\Delta H_{t 2}, \mathrm{~J} / \mathrm{g}$ \\
\hline Mint & -46.4 & 0.071 & -18.8 & 12.8 & 90.2 & 357 \\
\hline VEPUR & -61.7 & 0.086 & -19.8 & 8.8 & 58.8 & 62 \\
\hline VEPUR 10 & -63.1 & 0.085 & -24.7 & 6.3 & 74.3 & 120 \\
\hline VEPUR 20 & -62.9 & 0.136 & -27.4 & 12.0 & 85.2 & 148 \\
\hline VEPUR 30 & -62.8 & 0.153 & -27.9 & 11.0 & 92.4 & 153 \\
\hline
\end{tabular}

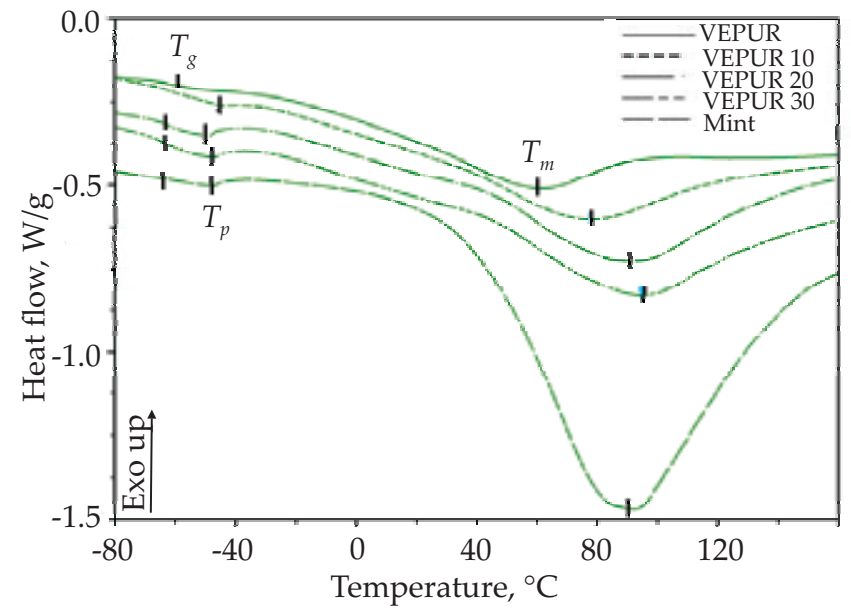

Fig. 10. Comparison of thermograms from DSC analysis

a)

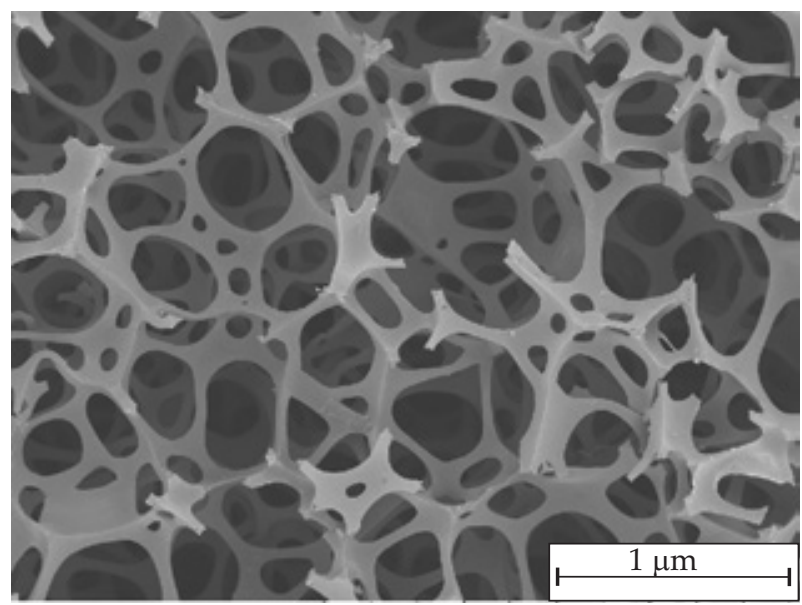

c)

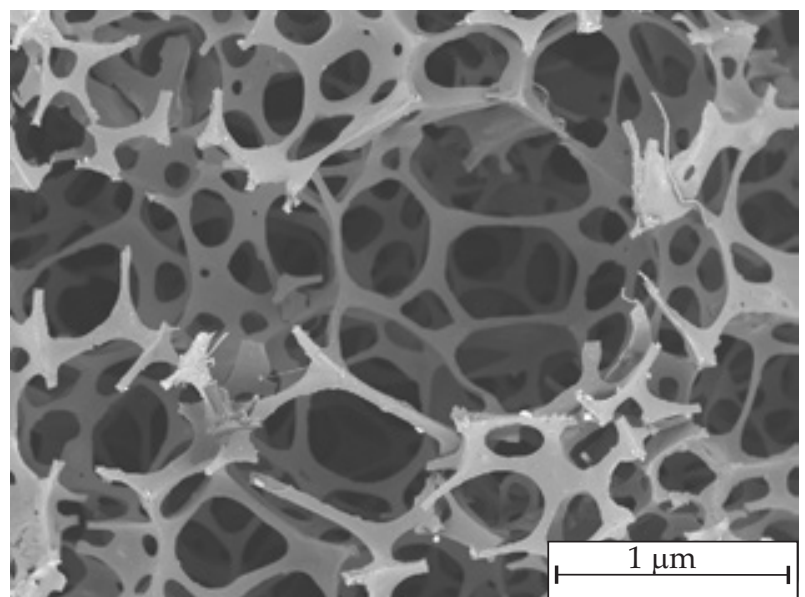

Typical viscoelastic foams are made from three phases: a soft phase, a phase composed of mixed flexible and rigid segments, and a hard phase [57]. During heating, typical changes for the structure of these phases are observed. The soft phase is described by the glass transition temperature, while the next two phases describe endothermic peaks associated with the change in order in these phases. In the tested VEPUR foam, the glass transition temperature was observed in the soft phase at about $-62{ }^{\circ} \mathrm{C}$, the temperature associated with the change in order in the phase composed of mixed flexible and rigid segments $\left(T_{t 1}\right)$ was about $-19.8^{\circ} \mathrm{C}$, and the change in order in the hard phase $\left(T_{t 2}\right)$ was approx. $59{ }^{\circ} \mathrm{C}$. The introduction of mint into VEPUR foam changes the characteristics of the glass transition and both transformations in composite foams. The more mint content, the greater the mo-

b)

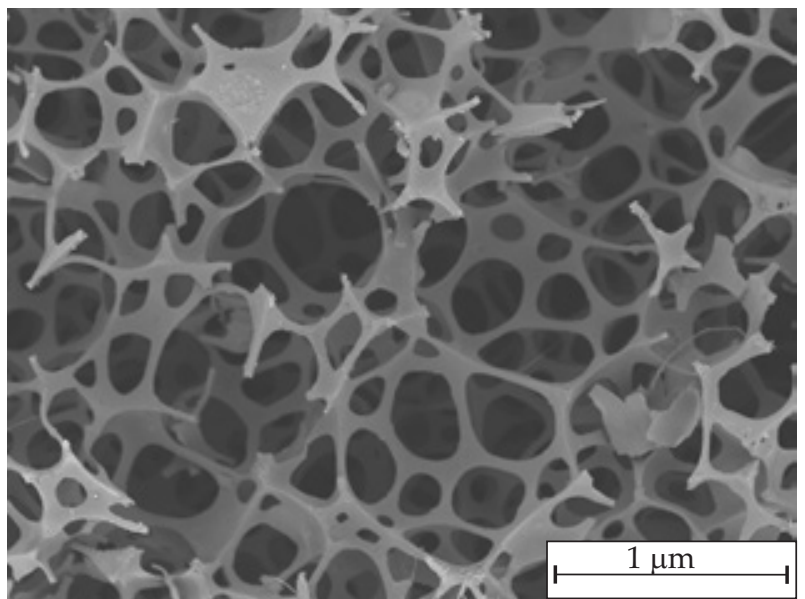

d)

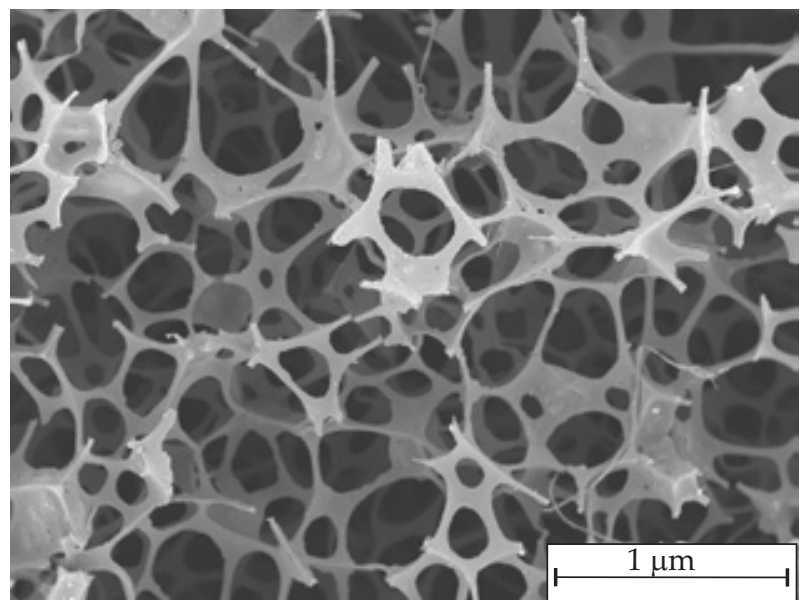

Fig. 11. SEM images of prepared foams macrostructure: a) VEPUR, b) VEPUR 10, c) VEPUR 20, d) VEPUR 30 
bility of the flexible segments of composite foams, which is indicated by the increase in the specific heat of glass transition $\left(\Delta C_{p}\right)$. Thermal effects associated with transformations in composite foams overlap with thermal effects occurring in the filler, resulting in an extension of the range between $T_{t 1}$ and $T_{t 2}$. The more mint added to the form, lower $T_{t 1}$ and higher $T_{t 2}$ values were observed. The introduction of more mint increased the enthalpy associated with the changes in both phases.

The introduction of a filler also caused the macrostructure of composite foams to change. SEM images of unmodified foams and composite foams are shown in Fig. 11.

The polyurethane foam and composite foams showed a regular open cell structure. The introduction of a filler increased the size of the largest pores in the foams, but also the pores connecting them.

In VEPUR 20 foam, both types of pores had the largest dimensions. In VEPUR 10 and VEPUR 30 foams, smaller pore walls are observed. The change in the structure of composite foams is the result of an increase in the amount of $\mathrm{CO}_{2}$ formed as a result of the reaction of water bound in the structure of the filler with NCO groups. Figure 12 shows SEM images showing the location of the filler in the matrix. The filler particles are built into the pore struts.

Changes in the micro- and macrostructure of foams after the introduction of the filler cause changes in their properties. Table 7 summarizes the results of the appa-

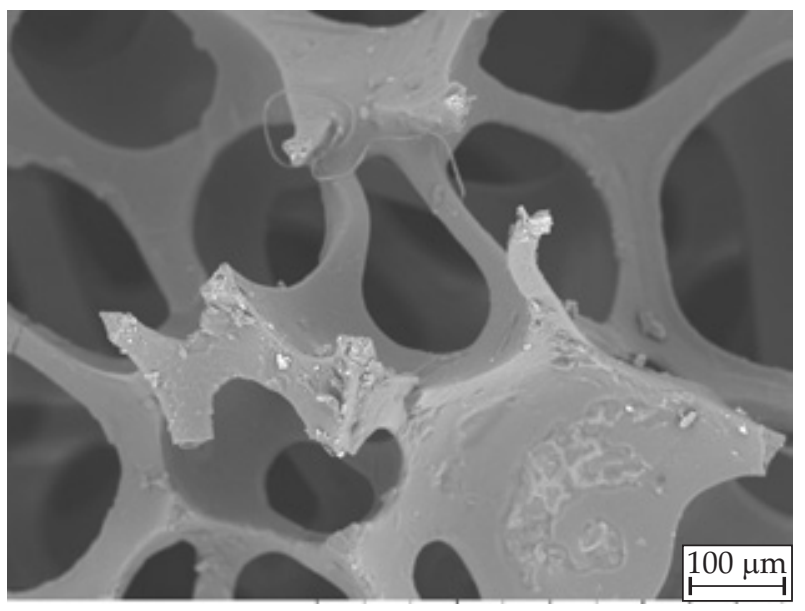

Fig. 12. SEM image showing the location of the filler in the matrix rent density $(D)$ determination, calculations of the theoretical value of apparent density $\left(D_{t}\right)$. In addition, the table also includes values determined during the fourth compression cycle: comfort factor $(S A G)$ and hardness parameter $\left(F_{40 \%}\right)$.

The apparent density increases with the amount of filler used. To explain the reason for these changes, the theoretical density of foams was calculated using the mixture rule for calculations. It was assumed that the density of the matrix in composite foams is equal to the density of VEPUR, and the density of mint leaves is equal to the density of meadow hay $\left(70 \mathrm{~kg} / \mathrm{m}^{3}\right)$ [54]. Figure 13 compares the results of analysis and calculations. The apparent theoretical density of composite foams was higher than the apparent density, the difference between the density values for composite foams increased as the amount of filler increased. These results indicate that the density of composite foams is influenced by the density of the filler, but also the increase in porosity caused by the reaction of water introduced with the filler and NCO groups of isocyanate.

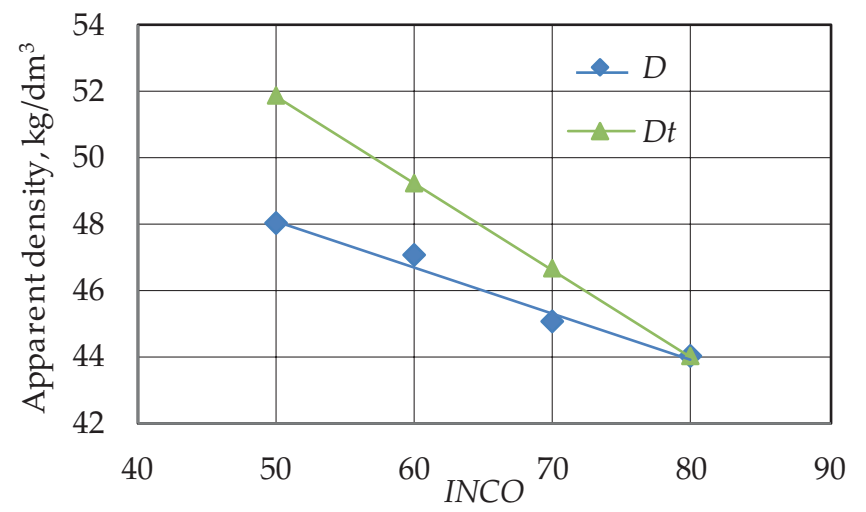

Fig. 13. Dependence of apparent density of prepared foams on their INCO value

The optimal range of the comfort factor of foams is between 2-4 and this is considered the most comfortable to use. Foams with a mint content of $0-20 \mathrm{wt} \%$ are in this range. The addition of mint brought about the most optimal value of the coefficient. The use of a $10 \mathrm{wt} \%$ of filler reduced the value of force at deformation by $40 \%$, and a further increase in its amount increased the hardness. The reduction in hardness for VEPUR 10 foam may

T a b l e 7. Properties determined in the compression test and apparent density of materials

\begin{tabular}{c|c|c|c|c|c}
\hline Sample & $D, \mathrm{~kg} / \mathrm{m}^{3}$ & $D_{t}^{*}, \mathrm{~kg} / \mathrm{m}^{3}$ & $\begin{array}{c}\text { Change in apparent } \\
\text { density, }\left(D_{t}-D\right) / D, \%\end{array}$ & $S A G$ & $F_{40 \%}, \mathrm{kPa}$ \\
\hline VEPUR & 44 & 44.0 & - & 2.1 & 2.4 \\
VEPUR 10 & 45 & 46.6 & 3.6 & 2.6 & 2.1 \\
VEPUR 20 & 47 & 49.2 & 4.7 & 3.4 & 2.4 \\
VEPUR 30 & 48 & 51.8 & 7.9 & 4.3 & 2.5 \\
\hline
\end{tabular}

* Apparent density of composites calculated according to mixture rules based on VEPUR density and assumed filler density of approx. $70 \mathrm{~kg} / \mathrm{m}^{3}$. 
be the result of a reduction in the thickness of the cell walls, despite the greater ordering of the hard phase of these foams and the incorporation of the filler in its spacers to increase hardness.

The reduction in pore wall thickness in composite foams is the result of an increase in the amount of $\mathrm{CO}_{2}$ formed after the introduction of the filler. A larger amount of filler increased the strength of the struts, which further increased hardness despite increasing the porosity.

Among the functional features of VEPUR foams is their permanent deformation after compression, e.g. during transport, but also during use. Table 8 summarizes the results of determining the value of permanent deformation for all tested samples. The VEPUR 20 and VEPUR 30 foams were significantly deformed as a result of the test, especially in the case of compression by $75 \%$ and $90 \%$ of the original height. Only deformations of the sample with a $10 \mathrm{wt} \%$ of mint content have permanent deformations with a value below the permissible limit of $10 \%$.

$\mathrm{T}$ a b 1 e 8. Results of permanent deformation of unmodified and composite foams after compression

\begin{tabular}{c|c|c|c}
\hline \multirow{2}{*}{ Sample } & \multicolumn{3}{|c}{ Permanent deformation, \% } \\
\cline { 2 - 4 } & $\begin{array}{c}\text { Compression } \\
\text { by 50\% }\end{array}$ & $\begin{array}{c}\text { Compression } \\
\text { by } 75 \%\end{array}$ & $\begin{array}{c}\text { Compression } \\
\text { by } 90 \%\end{array}$ \\
\hline VEPUR & 1.3 & 3.0 & 3.3 \\
VEPUR 10 & 2 & 6 & 10 \\
VEPUR 20 & 5 & 15 & 33 \\
VEPUR 30 & 7 & 28 & 40 \\
\hline
\end{tabular}

\section{Biological test results}

As a result of cytotoxicity studies presented in the work of Szczepkowski et al. [60], it was found that open cell viscoelastic foams produced at INCO $=90-100$ are cytocompatible.

The results of cytotoxicity tests on unmodified foam and mint composite foams are presented in Fig. 14.

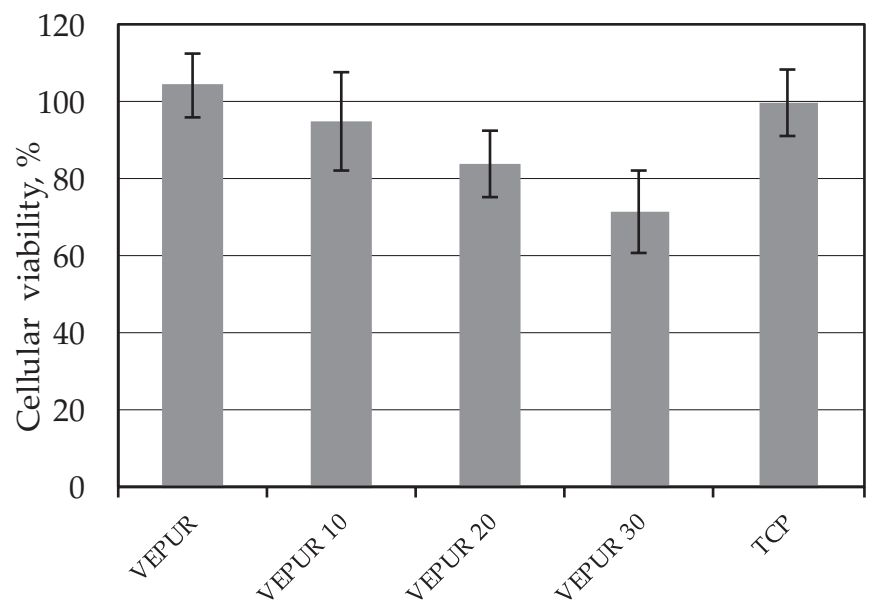

Fig. 14. Results of cytotoxicity assessment of prepared foams and reference sample TCP
In the presented article, open cell VEPUR foam was produced with an INCO =80, this foam is cytocompatible. The introduction of a filler causes the composite foams to become cytotoxic. The more filler, the greater the cytotoxicity of composite foams, but at $30 \mathrm{wt} \%$ of the filler, approximately $70 \%$ of cells survive. During unpublished cytotoxicity studies of open cell foams performed at various INCOs carried out during the implementation of the project work presented in the publication [60], it was found that at $I N C O<90$, foams became cytotoxic.

Based on these results, it can be concluded that the cytotoxicity of the obtained composite foams is the result of a decrease in their INCO caused by the reaction of NCO groups and water from the filler.

To confirm this assumption has been examined the effect of mint addition on the growth of Escherichia coli strain DH5a.

\section{T a b l e 9. Assessment of bacterial growth on a solid media}

\begin{tabular}{c|c|c}
\hline Sample & Part of area & SD \\
\hline VEPUR & 0.39 & 0.05 \\
VEPUR 10 & 0.32 & 0.06 \\
VEPUR 20 & 0.41 & 0.05 \\
VEPUR 30 & 0.37 & 0.07 \\
\hline
\end{tabular}

There was no statistically significant relationship between the presence of mint addition in the tested materials and the intensity of Escherichia coli growth on a solid agar medium (Table 9). Which confirms that the cytotoxicity of composite foams is the result of changes in the INCO.

\section{CONCLUSIONS}

The mint filler used to make composite foams is built like typical plant fillers made of hemicellulose, cellulose and lignin as well as secondary ingredients. The mint filler contains about $7 \mathrm{wt} \%$ of water. The microporous structure of the filler promotes fixing the filler to the matrix.

The average volumetric particle size of the filler is approx. $290 \mu \mathrm{m}$. This filler also contains about $7 \mathrm{wt} \%$ of bound water, phenols and amides, $15 \%$ hemicellulose, $26 \%$ cellulose and $12 \%$ lignin. VEPUR foam was made with an isocyanate index $I N C O=80$. Along with the filler, water was introduced into VEPUR, which caused the index of isocyanate composite foams to decrease as the amount of mint used increased. In composite foams, along with the increase in the amount of mint, the share of urea bonds increased. This change resulted in the formation of more hydrogen bonds in the hard phase of foams compared to VEPUR foam. The introduction of a filler caused a change in the thermal characteristics and thermal degradation of composite foams.

The introduction of a filler affected the change in apparent density of foams resulting from the introduction of a higher density filler and an increase in foam porosity. 
The hardness and comfort factor of composite foams also increased, which is significantly influenced by the change in the stiffness of the struts in which the filler particles are embedded. The introduction of a filler containing a significant amount of water caused a change in porosity and wall thickness of composite foams resulting in a significant increase in their permanent deformations. Only composite with $10 \mathrm{wt} \%$ of the filler has deformations less than $10 \%$, which may be the result of a significant share of hydrogen bonds strengthening the hard phase of its matrix and, as a consequence, increased elasticity.

The tested VEPUR foam is cytocompatible, but composite foams with mint were characterized by cytotoxicity resulting from a change in INCO caused by introducing into the mixture of substrates the water contained in the introduced mint leaves. The presented research results indicate that when using plant fillers, it is important to dry them before introducing the substrates into the mixture and to include the water contained in the filler in the foam formulation.

The addition of mint does not inhibit the growth of Escherichia coli DH5 $\alpha$. This may be related to the cytotoxicity of the materials.

This approach will allow the production of cytocompatible foam materials user friendly for use in the production of pillows and mattresses. Products from such materials will be able to be used in hospital rooms, public transport, nursing homes and others. However, when used as a mint filler, keep in mind that mint may cause allergic skin reactions.

\section{REFERENCES}

[1] https://www.mordorintelligence.com/industry-reports/natural-fiber-reinforced-composite foams-market (access data 5.09.2019)

[2] Pickering K.L., Aruan Efendy M.G., Le T.M.: Composite Foams: Part A 2016, 83, 98.

http://dx.doi.org/10.1016/j.composite foamsa.2015.08.038

[3] Salasinska K., Osica A., Ryszkowska J.: Polimery 2012, $57,646$.

http://dx.doi.org/10.14314/polimery.2012.646

[4] Salasinska K., Ryszkowska J.: Polimery 2013, 58, 461. http://dx.doi.org/10.14314/polimery.2013.461

[5] Salasinska K., Ryszkowska J.: Przemyst Chemiczny 2013, 92, 2027.

[6] Salasinska K., Ryszkowska J.: Composite Foams Interfaces 2012, 19, 321.

https://doi.org/10.1080/15685543.2012.726156

[7] Wolska A., Goździkiewicz M., Ryszkowska J.: Journal of Materials Science 2012, 47, 5693. http://dx.doi.org/10.1007/s10853-012-6394-2

[8] Salasinska K., Ryszkowska J.: Composite Interfaces 2015, 22, 39. http://dx.doi.org/10.1080/15685543.2015.984521

[9] Moustafa H., Youssef A.M., Darwish N.A. et al.: Composite Foams: Part B 2019, 172, 16. https://doi.org/10.1016/j.composite foamsb.2019.05.048

[10] Liu J., Willfo S., Xu C.: Bioactive Carbohydrates and Dietary Fiber 2015, 5, 31.

http://dx.doi.org/10.1016/j.bcdf.2014.12.001

[11] Tang W., Hemm I., Bertram B.: Planta Medica 2003, 69, 193.

http://dx.doi.org/10.1055/s-2003-38494

[12] Tang W., Hemm I., Bertram B.: Planta Medica 2003, 69, 97.

http://dx.doi.org/10.1055/s-2003-37718

[13] Harlev E., Nevo E., Lansky E.P. et al.: Planta Medica 2012, 78, 843. http://dx.doi.org/10.1055/s-0031-1298453

[14] Jin M., Huang Q., Zhao K. et al.: International Journal of Biological Macromolecules 2013, 54, 16. http://dx.doi.org/10.1016/j.ijbiomac.2012.11.023

[15] Li T., Peng T.: Antiviral Research 2013, 97, 1. http://dx.doi.org/10.1016/j.antiviral.2012.10.006-9

[16] Thakur M., Weng A., Fuchs H. et al.: Carbohydrate Polymers 2012, 87, 3. http://dx.doi.org/10.1016/j.carbpol.2011.08.035

[17] Tian L., Zhao Y., Guo C. et al.: Carbohydrate Polymers 2011, 83, 537. http://dx.doi.org/10.1016/j.carbpol.2010.08.023

[18] Najda A.: Postępy Fitoterapii 2017, 18, 251. https://doi.org/10.25121/PF.2017.18.4.251

[19] Shkurupiy V.A., Odintsova O.A., Kazarinova N.V., Tkachenko K.G.: Problemy Tuberkuleza i Boleznei Legkikh 2006, 9, 43.

[20] Derwich E., Chabir R., Taouil R. et al.: International Journal of Pharmaceutical Sciences and Drug Research 2011, 3, 130.

http://ijpsdr.org/index.php/ijpsdr/article/view/255

[21] Charles C., Chemais M., Stévigny C. et al.: Food Chemistry 2012, 135, 2974.

http://dx.doi.org/10.1016/j.foodchem.2012.06.112

[22] McKay D.L., Blumberg J.B.: Phytotherapy Research 2006, 20, 619. https://doi.org/10.1002/ptr.1936

[23] Peixoto I.T.A., Furlanetti V.F., Anibal P.C. et al.: Journal of Basic and Applied Pharmaceutical Sciences 2009, 30, 235.

[24] Rita P., Animesh K.D.: International Research Journal of Pharmacy 2011, 2, 1.

[25] Hufenbach W., Gude M., Geller S. et al.: Polimery 2013, $58,473$.

http://dx.doi.org/10.14314/polimery.2013.473

[26] Demiroglu S., Erdogan F., Akin E. et al.: Gazi University Journal of Science 2017, 30, 97.

[27] Kurańska M., Prociak A.: Composite Foams Science and Technology 2012, 72, 299. https://doi.org/10.1016/j.compscitech.2011.11.016

[28] Głowińska E., Datta J., Parcheta P.: Journal of Thermal Analysis and Calorimetry 2017, 130, 113. https://doi.org/10.1007/s10973-017-6293-5

[29] Bryśkiewicz A., Zieleniewska M., Przyjemska K. et al.: Polymer Degradation and Stability 2016, 132, 32. 
http://dx.doi.org/10.1016/j.polymdegradstab.2016.05.002

[30] Ryszkowska J., Auguścik M., Zieleniewska M. et al.: Tworzywa sztuczne w przemyśle 2016, 6, 72.

[31] Prithivirajan R., Jayabal S., Bharathiraja G.: Cellulose Chemistry and Technology 2015, 49, 65.

[32] „Biokompozyty z surowców odnawialnych” (Eds. Kuciel S., Rydarowski H.), Wydawnictwo Politechniki Krakowskiej, 2012.

[33] Radomski A.: „Chemia drewna”. http://andrzej_radomski.users.sggw.pl/chemia.html (access data 9.02.2014)

[34] Hołdyński Cz.: „Botanika leśna”. https://www.slideserve.com/anakin/botanika-lesna-wyklad- 2-sciana-kom-rkowa (access data18.10.2012)

[35] Krithiga N., Rajalakshmi A., Jayachitra A.: Journal of Nanoscience 2015, 2015, 1. http://dx.doi.org/10.1155/2015/928204

[36] Drożdż B., Tarsa M., Żylewski M.: „Spektroskopia IR", wyd. UJ, Collegium Medium, Katedra Chemii Organicznej w Krakowie. http://farmacja.cm-uj.krakow.pl/ mkz/skrypt_ IR.pdf; (access data 15.08.2019)

[37] Pielesz A., Biniaś D., Wieczorek J.: Polimery $w$ Medycynie 2011, 41, 33.

[38] Werle S., Ziółkowski Ł., Tomescu C. et al.: Proceedings of ECOpole 2017, 11, 443. http://dx.doi.org/10.2429/proc.2017.11(2)046

[39] Grabowska K., Osztyńska-Janus S., Detyna J.: „Interdyscyplinarność badań naukowych" (Ed. Szrek J.), Politechnika Wrocławska, Wrocław 2013, p. 238.

[40] Lyman D.J., Benck R., Dell S. et al.: Journal of Agricultural Food Chemistry 2003, 51, 3268. https://doi.org/10.1021/jf0209793

[41] Sadeghi B., Gholamhoseinpoor F.: Spectrochimica Acta Part A: Molecular and Biomolecular Spectroscopy 2015, 134, 310. http://dx.doi.org/10.1016/j.saa.2014.06.046

[42] Yan-Yu R., Hui Y., Tao W. et al.: Physics Letters A 2016, 380, 3773.

https://doi.org/10.1016/j.physleta.2016.09.029

[43] Szczerbowska-Boruchowska M.: Pomiary Automatyka Kontrola 2007, 53 (9 bis), 444.

[44] Sałasińska K.: „Kompozyty polimerowe z napełniaczami pochodzenia roślinnego otrzymywane z materiałów odpadowych", Politechnika Warszawska, Warszawa 2014.

[45] Kociszewski M., Gozdecki C., Wilczyński A. et al.: European Journal of Wood and Wood Products 2012, 70, 113. http://dx.doi.org/10.1007/s00107-011-0531-5

[46] Ryszkowska J.: „Materiały poliuretanowe wytwarzane z zastosowaniem surowców odnawialnych", Oficyna Wydawnicza Politechniki Warszawskiej, Warszawa 2019, p. 139.

[47] Väisänen T., Haapala A., Lappalainen R. et al.: Waste Management 2016, 54, 62. https://doi.org/10.1016/j.wasman.2016.04.037

[48] Fengel D.: Wood Science and Technology 1969, 3, 203. https://doi.org/10.1007/BF00367212

[49] Yao F., Wu Q., Lei Y. et al.: Polymer Degradation and Stability 2008, 93, 90. https://doi.org/10.1016/j.polymdegradstab.2007.10.012

[50] Ramiah M.V.: Journal of Applied Polymer Science 1970, $14,1323$. https://doi.org/10.1002/app.1970.070140518

[51] Prociak A., Rokicki G., Ryszkowska J.: „Materiały poliuretanowe", PWN, Warszawa 2016.

[52] Piszczyk Ł., Hejna A., Formela K. et al.: Polimery 2014, $59,783$.

http://dx.doi.org/10.14314/polimery.2014.783

[53] Kumar B., Noor N., Thakur S.: ACS Omega 2019, 4, 15348. http://dx.doi.org/10.1021/acsomega.9b01167

[54] Zieleniewska M., Ryszkowska J., Bryśkiewicz A. et al.: Polimery 2017, 62, 127. http://dx.doi.org/10.14314/polimery.2017.127

[55] Chen Y., Zhang L., Du L.: Industrial \& Engineering Chemistry Research 2003, 42, 6786. https://doi.org/10.1021/ie0301381

[56] Ryabov S., Kotelnikova N., Kercha Y.: Macromolecular Symposia 2001, 164, 421. https://doi.org/10.1002/1521-3900(200102)164:1<421::AID-MASY421>3.0.CO;2-D

[57] Bernardini J., Angullesi I., Coltelli M.B.: Polymer International 2015, 64, 1235. https://doi.org/10.1002/pi.4905

[58] Demirci F., Yildirim K., Kocer H.B.: Journal of Applied Polymer Science 2018, 135, 45914. https://doi.org/10.1002/app.45914

[59] http://www.zootechnik.com/downloads/Gestosc\%20 materialow\%20pochodzenia\%20roslinnego $\% 20 \mathrm{i} \% 20$ zwierzecego.pdf (access data 20.09.2019)

[60] Szczepkowski L., Ryszkowska J., Auguścik M. et al.: Polimery 2018, 63, 679. http://dx.doi.org/10.14314/polimery.2018.10.3

Received 30 IX 2019. 